\title{
The social and clinical determinants of proportions between paternalism and partnership in therapeutic relationships in medicine
}

\begin{abstract}
The subject of the article are the contextual determinants of the formula of the therapeutic relationship in medicine with regard to the proportions between paternalism and partnership. The article was inspired by the results of two recent editions of the Organisation for Economic Co-operation and Development (OECD) "Health at a Glance" studies of 2015 and 2017 ; in their light, Poland ranks at the bottom of ratings concerning patient satisfaction with communication with doctors. According to these studies, the therapeutic relationship in medicine in Polish society appears to be petrified in the paternalist formula, not sufficiently taking into account the autonomy and agency of patients. Based on the analysis of the determinants of a broader tendency, described in Western studies, consisting in the wider development of partnership relationships between doctors and patients, the study will show individual barriers, social ones, including structural and institutional, as well as clinical barriers to implementation in medical practice of the partnership model of therapeutic relationships in medicine, which assumes the active involvement of patients in clinical decision-making as well as in the processes of medical treatment.
\end{abstract}

Keywords: physician-patient interaction, empowerment, socioeconomic status, social health inequalities, paternalism and partnership in medicine, medical sociology.

DOI: $10.1515 /$ pjph-2017-0038

\section{INTRODUCTION}

The article focuses on the problem of the determinants of proportions between paternalism and partnership in medicine and also on the related issues of the empowerment of patients in the therapeutic relationship which will be shown as a necessary condition for the active participation of patients in the process of medical treatment. Investigation of these problems, not only in the field of social sciences (included by the author of the present study in the earlier publications) [1-4] but also in the field of medicine and public health, is justified in the context of the results of two recent editions of the OECD "Health at a Glance" studies of 2015 and 2017, whose aim was to assess the quality of communication with doctors in outpatient care. The studies included, inter alia, the following aspects of the doctor-patient relationship: devoting enough time to the patient, explaining the medical issues to the patient in a clear and intelligible way, and involving the patient in the decisionmaking process. The results concerning each of the aspects of the doctor-patient relationship assessed in the project in both editions of the program were unfavorable for Poland. They suggest that the therapeutic relationship in medicine in the realities of Polish society is petrified in a paternalistic formula and does not sufficiently take the agency of patients into consideration. The Poles, in comparison with citizens of other OECD countries, do not very highly evaluate the state of realization/implementation of the partnership model of the therapeutic relationship in the Polish system of health protection, and, as a result, Poland is placed at the bottom of the ranking of the level of patients' satisfaction with communication with doctors $[5,6]$.

Let us examine particular results of the studies. The duration of a visit in the edition of 2017 was evaluated as satisfactory only by $59.6 \%$ of Polish patients; (only Japan was worse $-39 \%$ of unsatisfied patients), the average for OECD-18 being $81.3 \%$ of satisfied patients. In this aspect of studies, in the previous edition of the "Health at a Glance" studies of 2015, Poland ranked as the last (the average for OECD 19 countries was then $84.9 \%$ ). In the case of countries with the highest notes, the percentage of satisfied patients was, for example, $97.5 \%$ in Belgium, or $97.2 \%$ in the Czech Republic. In the category concerning the explanation of medical problems in a clear and intelligible way (the patients were asked about their experiences with their regular doctor), the highest scores were achieved in 2015 by Belgian doctors (97.8\%) and Luxembourgian doctors $(97.5 \%)$, the average for OECD-19 being $87.9 \%$; according to Polish respondents, only $69.5 \%$ of doctors fulfilled the criteria (it was then the bottom ranking in this category). In 2017 Poland also came last (with the average for OECD 17 being $88.9 \%$ ). The next aspect of the studies concerned the involvement of patients in the decision-making process: in 2015 only $47.9 \%$ of patients in Poland had such an experience. The average for OECD-19 countries was $81.3 \%$ in the same year; the best evaluated were doctors working in Luxembourg (95.5\% of satisfied patients) and Belgium (95.1\% of satisfied patients) [5]. In 2017, Poland also came last in this 
ranking (the average for studied OECD countries was $83 \%$ of satisfied patients). Thus, the position of Poland at the bottom of the ranking did not change in 2017 in comparison with the results of the previous edition of studies. In the earlier analysis conducted by A. Ostrowska, who based her studies on the results of European Health Survey (EHS) of 2004, Poland also occupied the last position in the group of 17 European countries on the scale of cooperation between doctors and patients, which meant that therapeutic relationships were at that time evaluated by Poles as paternalistic [2]. Taking the presented OECD results into consideration, one can state that the situation diagnosed as part of the EHS did not change significantly $[5,6]$.

\section{The patient's agency regarding health issues as a factor determining the degree of retained autonomy in the thera- peutic relationship}

In view of the quoted results, the analysis of determinants of proportions between paternalism and partnership in the doctor-patient relationship, and particularly the search of the causes of the situation in which therapeutic relationships in Polish medicine seem to be fixed on a paternalistic formula, is justified. While undertaking the analysis with such profile, some starting observations should be made. The author advances the thesis that the paternalistic formula of the doctorpatient relationship should be treated as a customary, reactive formula of treatment, dependent on the social, clinical, and individual specificity of a concrete therapeutic situation [cf. 7] rather than as a basic, starting pattern or a model of the therapeutic relationship from which one lean more towards a strongly marked partnership. A partnership model is the basic model of the therapeutic relationship because it constitutes an expression of indispensable autonomy and the right to selfdetermination of an adult patient. As Jan Hartman, on the basis of bioethics, writes, "autonomy is not something that the doctor gives the patient $[\ldots]$ autonomy is something that the patient possesses independently from the doctor's views on the issue of paternalism" [7]. In turn, in the sociology of medicine, A Ostrowska stresses that in the realities of medical practice both models of the therapeutic relationship (i.e. the paternalistic model and partnership model) rarely occur in a pure form and doctors face the situations which can be located at various points of the continuum between paternalism and partnership [2]. According to Ostrowska, one may speak about "the degree of the patient's retained autonomy $[\ldots]$ depending on the adopted model of mutual interaction between him/her and the doctor" [2], and in the partnership model the patient's autonomy is manifested to a larger degree than in the paternalistic model. The empowerment of lay people regarding health and treatment issues seems to be the basic condition for the emergence of the partnership model of the therapeutic relationship in medicine. Z. Słońska proposes to understand this notion as "the causative power of individuals or society manifested in autonomous, spontaneous, creative, and effective activities in the process of exercising authority and control over health of an individual and of a community. Agency, thus understood ensures autonomy and participation in making health-related decisions $[\ldots]$ and the access to resources that decide about health" [8]. A layperson empowered on health issues has a real causative power in actions for health and is equipped with the prerogative of "agency" in respect of health. It means that s/he has larger control over health because s/he receives greater power which enables him/her to undertake active measures regarding health and treatment issues. In the course of further analysis, the social determinants of the patient's empowerment on health issues will be specified.

\section{Historical changes in the doctor-patient relationship from the sociomedical perspective}

The doctor-patient relationship is a sine qua non condition for medical practice (excluding special situations e.g. when the patient is unconscious) and the quality and formula of this relationship, including the proportion between paternalism and a partnership, influences the effectiveness of treatment and the level of patient's and doctor's satisfaction. Sociomedical analyses with such characteristics are located within a branch of the sub-discipline called "sociology of medicine" by Robert Straus [9]. They were initiated by an American sociologist Talcott Parsons who, in the 1950s, described the model of doctor-patient relationship as a model of compliance or a model of complementary social roles [10]. He then suggested that both sides of the relationship need each other and despite differences in the attitude to the illness they cooperate because they are inspired by the same aim i.e. seeking to recover from illness. Parsons stressed that the status of participants in the therapeutic relationship in medicine is not equal: the doctor has an advantage of power and "technical" competence because $\mathrm{s} / \mathrm{he}$ has exclusive rights regarding treatment [10] and possesses the prerogative of legitimizing the social role of the patient. According to Talcott Parsons, the doctor-patient relationship is of paternalistic character [10] and is characterized by distinct asymmetry: the doctor has power, authority and a dominant position, s/he is an expert-professional and the position of the patient is characterized by dependence and subordination [11]. The model of the therapeutic relationship described by Parsons, which is an element of the sociological description of American society of the 1940s and 1950s, became a starting point for chronologically subsequent sociological analyses in which attention was focused on the process of changes in doctor-patient relationships consisting in shifting towards partnership in the therapeutic relationship in medicine. It was stressed that this was a consequence of the declining social status of medicine and of the growing agency of laypeople in the processes of healthcare. In the period from the 1960s to the 1980s the high social status of medicine and its definite domination in the field of healthcare was reported and the resulting asymmetry in doctor-patient relationships in which the doctor dominated, then since the 1990s sociologists described the causes, manifestations, and consequences of the erosion of authority and dominance of medicine, at the same time drawing attention to parallel processes of the growing role of laypeople in healthcare. The processes led to the reduction of the former asymmetry in doctor-patient relationships and to the formation, to a greater degree, of the partnership model of therapeutic relations [12].

\section{Selected inspirations of the shift towards partnership in the doctor-patient relationship}

An important cause of the foregoing changes was consumerist trends in healthcare which had been observed in the USA since the 1960s; they became especially noticeable in the 1980s. As A. Ostrowska shows, measures were taken as part of these trends "to make medical knowledge available to patients and to activate them in the relationships with doctors" [1]. 
The creation of the patient-consumer model, in which s the makes conscious and informed choices concerning health and healthcare issues was connected with undermining of confidence in medicine and with a growing number of complaints and legal proceedings regarding malpractices, with a greater involvement of patients in making clinical decisions and also with the more common use of alternative methods of treatment [13]. A greater participation of patients than previously in the processes of medical treatment was also the result of epidemiologic transition, which took place in the mid- $20^{\text {th }}$ century. As a result, the structure of health risks in the Western societies was dominated by non-communicable chronic diseases (NCD), whereas the threat of infectious diseases diminished. The "stage" of chronic diseases became thus an everyday life of patients rather than institutional medicine which played its role only in planning a long-lasting treatment and its periodical monitoring, and also in chronic disease exacerbations. The context of being ill thus changed, moved from medical institutions to the area of everyday life. This fact has been documented since the 1970s by American sociologists who represent the theoretical tradition of symbolic interactionism. Studies on this problem were initiated in the publication of Anselm Strauss and Barney Glaser of 1975, "Chronic Illness and the Quality of Life" [14], in which attention was drawn to a new context of chronic illness - everyday life but also to challenges arising to the patient therefrom, and consisting in the necessity of organizing one's life despite one's illness. The authors of the book develop the concept of the trajectory of the illness, drawing attention to the changing efforts of patients to cope with their illness. Strauss and Glaser emphasize that patients face the challenge of simultaneously doing several kinds of work that the illness entails i.e. "illness work" resulting from the regimes of medical treatment, "everyday life work" that involves doing everyday family, professional duties and etc., and "biographical work" [15]. The third of the abovementioned terms shows that the consequences of illness go beyond everyday life activities and also concern the problems of personal identity and personal biography of patients that need to be adjusted to the new situation of chronic illness [14]. The model of chronic disease, created in the trend of sociological studies in question, strongly enhances the active role of laypeople in the process of being ill, who were equipped with the abovementioned prerogative of agency in relation to their illness [16]. It is manifested in the active participation in the process of treatment, reorganization of everyday life resulting from illness requirements, and also in innovatively constructing a new picture of oneself in illness as well as in the reconstruction of personal biography and its adjustment to a new life situation $[17,18]$. An important element of the trend of sociomedical studies in question, is the concept of American sociologist, Eliot Freidson, who analyzed the activity of laypeople in the processes of reaction to the appearance of illness symptoms. As part of the concept of lay reference system, this scholar pointed out that a layperson could play the role of a health consultant (this is evident when analyzing the social phenomenon of complementary and alternative medicine, CAM) and the lay system constitutes an important reference system in which many decisions on health are taken, especially the ones concerning help-seeking behavior $[19,20]$.

\section{The patient empowered by the Internet and contemporary transformations of doctor-patient relationships}

The concepts of sociologists representing the American interactionist tradition can be treated as an accurate forecast of future transformation of the ways of experiencing illness and doctor-patient relationships in the $21^{\text {st }}$ century, connected with the phenomenon of e-Health i.e. with the use of modern information and communication technologies in order to transfer information on health among both consumers of health services and entities that offer medical services $[21,22]$. The author will, at this point, omit the discussion on the issues concerning the Internet presentation of experiencing illness, searching and giving support in illness on the Internet social webs, or the criticism of institutional medicine [3,23-28]; attention will be drawn only to the phenomenon of laypeople's "information work" concerning health and illness, carried out on the basis of Internet resources. A. Maksymowicz says that 93\% of Polish Internet users search the Web for information on health [29], what means that this is one of the most important motives for using the Internet. I am not going to dwell here on the critical analysis of the quality of the Internet data on health and ways of using the information on health that can be found on the Internet [30] and I assume that there are also available scientifically verified and credible sources of information about health e.g. web pages of medical scientific associations, medical institutions etc. Experts studying this problem agree that as a result of the general availability of the Internet, expert medical knowledge (until now reserved only for medical professionals or graduates of medical profession, and contained in medical books and magazines), has become relatively easily accessible for ordinary people [3,23]. It is thus suggested that as a result of this, the process of democratization of medical knowledge takes place [3] as well as its deprofessionalization, that is we are dealing with the situation in which professionals lose their exclusive monopoly of the access to medical knowledge [31]. This leads to eliminating the difference in the level of the knowledge gap between medical professionals and ordinary people [12] and in consequence, there is a greater empowerment of laypeople on issues relating to health and illness. The process of democratization of medical knowledge is conducive to the diminishment of asymmetry of power distribution in therapeutic relationships and enables the shift towards the partnership model (or its restitution, if we assume that this model is the base of therapeutic relationships in medicine) characterized by the diminishing domination of doctors over patients, in which the Internet-empowered patient actively participates. However, it should be made clear that this situation, when there is an increase in the level of health literacy, is the result of laypeople's participation in Internet forums and is based on the use of non-professional sources of information about health, therefore we are dealing with the process of self-empowerment of laypeople on health issues.

\section{Socioeconomic determinants of the empowerment of lay- people in therapeutic relationships}

Determinants of the participation of patients in the processes of medical care and implementation of the partnership model concerning doctor-patient relationship connected with the social situation of patients and doctors will be the subject of this paragraph. The socioeconomic status (SES) evaluated in terms of education, income, and occupation is treated as an indicator of the position in social structure [32]. The author 
has been inspired to investigate this theme by the phenomenon of social health inequalities, which are regarded as one of the most important challenges to modern public health. Social health inequalities manifest themselves in the unequal access to health as well as to health-determining resources that depend on the position of individuals and groups in the structure of society. As interpreted by the WHO, social differences in the state of health are "unnecessary and avoidable" and, furthermore, are perceived as "unfair and unjust" [33]. The scope of this phenomenon is very wide; according to the results of the European Community Household Panel [34] carried out in the EU member countries between 1994 and 2001 on a sample of 74,000 people in each European community, people with a high SES are in a better health situation although the range and scale of the problem differ in particular European countries [35]. In Poland, despite the improvement of the health state connected with the results of system transformation [36,37], health differences between social groups resulting from the gradationally diversified socio-economic conditions of life and work are growing [33]. Especially pronounced differences in the state of health in Poland depend on the level of education: the average life expectancy of men aged 25 with post-secondary school or university education was longer by 13 years (women - 9 years) in 2002 in comparison with people with primary education, these differences continuing to grow if one takes into consideration the healthy life expectancy. The differences in health that depend on the level of education are greater in Poland than the average for the EU countries [33]. The mechanisms of influence of the social position on the determinants of health (the author will omit this type of studies because they do not belong to the main theme of this analysis) are the subject of many analyses in the field of public health and medical sociology, inspired by the content of the Black Report. The scholars also draw attention to the important influence of patients' social situation on the formula of therapeutic relationships and ways of utilization of the medical system. On the basis of Western studies, a thesis is formulated that the patient's lower social position is more likely to make the therapeutic formula more paternalistic due to weaker participation of the patient in decision-making processes. According to A. Ostrowska this thesis can be generalized and treated as universal for capitalist societies [2]. Possible explanations of this relationship emphasize the following issues: firstly, A. Ostrowska points out that the "main assumptions on which the structure of health services is based are in accordance with the values, expectations, and styles of life of, first of all, the middle class" and at the same time "the patterns of socialization in the middle class equip an individual with skills in carrying out the role of the patient more easily, in understanding the objective orientation of representatives of health service, and in minimizing a small difference in status" [2]. Moreover, she stresses that the specificity of socialization in the middle class facilitates the knowledge of structure of the medical system and better prepares one to effectively express one's own stance during consultation with a doctor [2]. The higher level of education, in turn, makes more probable the emergence of partnership in the therapeutic relationship because it generally involves a higher level of medical knowledge and culture [2]. A greater probability of the paternalistic model of the doctorpatient relationship may therefore be interpreted (at least partly) as a consequence of the information exclusion of people at the bottom of social structure, which leads to the situation in which, due to his/her incompetence, the patient can neither participate in a realistic way in the decision-making process nor in treatment, leaving the decision-making to the doctor. A. Ostrowska also draws attention to the importance of the specificity of health culture (an element of the culture of poverty) of social groups ranking low in the social structure whose characteristic features are fatalistic interpretations of health ("what will be, it will be"). In their context, what is rational is not so much activity in the health sphere, or the selfcreation of health, but rather passivity and acceptance of the fate [2]. It seems therefore that empowerment on health issues, determining the ability of partnership in the doctor-patient relationship, is difficult to achieve in the lowest layers of the society both due to deficits in knowledge making it impossible to take over responsibility for health and because of the specificity of ways of understanding health, revealed in the studies carried out from the perspective of interpretative sociology. This situation adversely affects the possibilities of implementing the negotiation-based partnership model of the therapeutic relationship and results in the incomplete, limited manifestation of the patient's autonomy inalienable from the ethical point of view. In the case of persons with low socioeconomic status, the possibility of partnership and negotiations in doctorpatient relationships is also adversely affected by the distinct social distance between the doctor and the patient, with regard to social and material status and also intellectual abilities [1].

Taking the state of Polish studies into consideration, A. Ostrowska in 2011 pointed to the fact that the interrelations described in Western literature concerning the doctorpatient relationship which associate higher social status with the partnership formula of doctor-patient relationships, had not yet clearly manifested themselves in Poland. She then predicted that it is only in the future that there will be diverse ways of utilizing the medical system in Poland, depending on social status and consisting in the fact that people belonging to the middle class will follow "the pattern characteristic of consumer relations in which the patient is a client who makes a conscious informed choice", whereas people belonging to lower social classes will be "passive consumers of available [medical] services" [2]. Interpreting the situation in Poland, consisting in domination of the paternalistic model of therapeutic relationships in medicine, she pointed out that this might result from "the heritage of socialism" consisting in the fact that there is a unified attitude of doctors towards patients, which was formed in the previous system. She anticipated that "it is only with the progressing consolidation of social divisions characteristic of capitalism" that in Poland the differences described in Western countries concerning using the medical system between middle-class patients and the ones from the lower classes would become more apparent [2]. The author does not know any data (as of 2018) that would allow him to verify this hypothesis; we can, therefore assume that A. Ostrowska's diagnosis is still relevant.

This analysis will not be complete without saying that the domination of a medical professional (connected with distance in the doctor-patient relationship) has a functional value in many clinical situations. The doctor's domination is, firstly, a necessary condition in performing procedures connected with interference with the patient's intimacy. In such situations, "the shortening of the distance" between doctor and patient (this concerns e.g. gynecological or urological examinations) may lead to the infringement of the patient's dignity [2]. 
The effectiveness of treatment, in the sense of the so-called doctor's charisma or possibility of the placebo effect are also connected with doctor's domination and authority, and consequently, with the asymmetry in power distribution in the therapeutic relationship [1]. We cannot rule out that in the circumstance of complete disappearance of asymmetry in the doctor-patient relationship, a situation may arise in which treatment will be impossible.

\section{Individual, clinical and institutional determinants of lay- people's participation in medical treatment processes}

The model of a layperson who actively participates in the processes of medical care cannot be uncritically generalized also due to individual preferences of patients as to the formula of the therapeutic relationship, and also due to clinical reasons (medical specification of a disease, a phase of the disease) and institutional ones (public or private entity, etc.). Recognition of patients' preferences as to the formula of therapeutic relationships should take place in the doctor-patient dialogue. By talking with the patient, the doctor receives information on the degree of the patient's desired participation in making decisions concerning clinical treatment. Clinical determinants, in turn, determine whether and to what extent, desired and declared by patients way of participation in the processes of medical care can be implemented in practice. The specificity of a clinical situation determines whether during treatment there is "room for negotiations" between the doctor and the patient. This question is clearly elucidated by the classification of the doctor-patient relationship by T. S. Szasz and M. H. Hollender. The first classified type of the doctor-patient relationship, The Model of Activity-Passivity, manifesting itself in the activity of the doctor and passivity of the patient; it occurs in emergencies in which the patient's consciousness is suspended like e.g. during anesthesia, a diabetic coma, etc. The authors of the concept show that in this model "treatment takes place irrespective of the patient's contribution and regardless of the outcome" [38]. The second type of relationship, described as The Model of Guidance-Cooperation, comprises the situation in which the patient is able to cooperate with the medical staff. However, the doctor retains the dominant position and the patient follows his/her directives (such situation takes place in emergencies but the patient is conscious). The third type of the doctor-patient interaction, The Model of Mutual Participation, concerns a situation of the patient's co-participation in the process of treatment (e.g. in chronic diseases). The distribution of power in this kind of relationship is more equal [38]. In this conception, the proportions between paternalism and partnership were expertly relativized to the specificity of clinical situation. When discussing the clinical determinants of "room for negotiations" (A. Ostrowska's expression) [2] in the doctor-patient relationship, we should also draw attention to the functional requirements of surgical treatment, where it is in resolute action and in enforcing the paternalistic formula of treatment that one can see the condition for its effectiveness [39]. The type of therapeutic relationship also depends on the institutional context of treatment, including the way of organization of medical care. A. Ostrowska points out that a sole-practitioner physician attaches special importance to the level of patients' satisfaction which, as is known, depends to a greater extent on the affective layer of the doctor-patient relationship, concerning the non-medical needs of patients, and, consequently, s/he will put greater emphasis on the agency of patients. A doctor who works as part of a team, will, in turn, be probably governed more by the preferences of his/her professional milieu even if this entails patients' disapproval [1]. Also according to American sociologist, Eliot Freidson, the doctor with solo-fee-for-service practice is ready to take measures which will satisfy the patient (".... much of the excessive prescribing of antibiotics, barbiturates, tranquilizers, and other drugs must be ascribed to pleasing the patient"). In such situation, as Freidson observes, the doctor is away from the pressure from his/her colleagues, which could correct such attitude [40].

\section{Conclusion: paternalism or partnership in Polish medicine - an attempt of diagnosis}

The trend of the diminishing asymmetry in the doctorpatient relationships for the increased agency of patients and their greater participation in therapeutic treatment, is a social fact documented in Western studies. In 2011, on the basis of contemporaneous state of Polish sociological inquiries, A. Ostrowska said that in Poland "the processes of dissemination of the partnership model are in progress even if they are only in the crystallization phase" [2]. In view of the results of studies (discussed in the Introduction), carried out in the OECD countries as part of the two last editions of the project "Health at a Glance" of 2015 and 2017, the foregoing diagnosis is still relevant today and there are no grounds for claiming that partnership relationships between doctors and patients have become widespread in Poland.

The theses about patients' increased agency in relationships with medicine, which would result in the rise of the phenomenon of "expert-patient" [41] and in the new formula of the doctor-patient interaction described as "a meeting between experts" [42], should not be generalized for the above-specified reasons because the formula of therapeutic relationship in its aspect that concerns the proportion between paternalism and partnership is dependent on many variables - individual, social, and clinical ones. Certainly, however, the doctor should show flexibility in building relationships with patients, adjusting his/her formula to patients' preferences, to their (patients') actual possibilities of active participation in therapeutic treatment, and also to the clinical situation, bearing in mind that patients' autonomy is a legal fact and is inalienable. Actions for the dissemination of the partnership model of the therapeutic relationship in medicine may be treated as actions supporting the manifestation of patients' inalienable autonomy.

\section{REFERENCES}

1. Ostrowska A. Modele relacji lekarz-pacjent. In: A. Ostrowska (ed). Socjologia medycyny. Podejmowane problemy, kategorie analizy. Warszawa: Wyd. IFiS PAN; 2009. p. 235-9.

2. Ostrowska A. Paternalizm i partnerstwo. Społeczny kontekst relacji lekarzpacjent. In: J. Hartman, M. Waligóra (eds). Etyczne aspekty decyzji medycznych. Warszawa: Wyd. LEX, a Wolters Kluwer Business; 2011. p. 11-22

3. Gałuszka M. Nowe zjawiska w relacji lekarz-pacjent w kontekście rozwoju Internetu. Przeg Socjol. 2012;61(2):139-40.

4. Skrzypek M. Ewolucja relacji lekarz-pacjent w kontekście upodmiotowienia laików w opiece zdrowotnej. In: J. Szymczyk (ed). Zaufanie społeczne: teoria - idee - praktyka. Warszawa: Oficyna Naukowa; 2016. p. 349-69.

5. oecd-ilibrary.org [Internet]. Health at a Glance 2015: OECD Indicators; c2015 [cited 2016 Jan 20]. Available from: dx.doi.org/10.1787/health glance-2015-en.

6. oecd-ilibrary.org [Internet]. Health at a Glance 2017: OECD Indicators; c2017 [cited 2018 Apr 27]. Available from: https://www.oecd-ilibrary.org/ social-issues-migration-health/health-at-a-glance-2017_health_glance2017-en. 
7. Hartman J. Bioetyka dla lekarzy. Warszawa: Wyd. LEX, a Wolters Kluwer Business; 2012. p. 105-7.

8. Słońska Z. Wkład polskiej socjologii w rozwój promocji zdrowia. Od socjologii medycyny do socjologii w promocji zdrowia. In: A. Ostrowska, M. Skrzypek M (ed). Socjologia medycyny w Polsce z perspektywy półwiecza: nurty badawcze, najważniejsze osiągnięcia, perspektywy rozwoju. Warszawa: Wyd. IFiS PAN; 2015. p. 126-7.

9. Straus R. The nature and status of medical sociology. Am Sociol Rev. 1957;22(2):200-4

10. Parsons T. System społeczny. Kraków: Wyd. Nomos; 2009.

11. Parsons T. Illness and the role of the physician: a sociological perspective. In: Stoeckle JD, ed. Encounters between patients and doctors: an anthology. Cambridge: The MIT Press; 1987. p. 147-56.

12. Elston MA. Medical autonomy and medical dominance. In: J. Gabe, M. Bury, MA Elston (eds). Key concepts in medical sociology. London: Sage; 2006. p. 173-7.

13. Elston MA. Decline of medical autonomy. In: J. Gabe, M. Bury, MA. Elston (eds). Key concepts in medical sociology. London: Sage; 2006. p. $178-83$.

14. Strauss LA, Glaser BG. Chronic illness and the quality of life. Saint Louis: The C.V. Mosby Company; 1975.

15. Corbin J, Strauss A. Managing chronic illness at home: three lines of work. Qual Sociol. 1985;8(3):224-5.

16. Skrzypek M. Perspektywa chorego w socjologii choroby przewlekłej. Ujęcia teoretyczne, ich ewolucja i recepcja. Lublin: Wyd. KUL; 2012.

17. Charmaz K. Loss of self: a fundamental form of suffering in the chronically ill. Sociol Health Ill. 1983;5(2):168-95.

18. Charmaz K. Struggling for a self: identity levels of the chronically ill. In: JA. Roth, P. Conrad (eds). Research in the sociology of health care. A research annual. The experience and management of chronic illness. Greenwich-London: JAI Press; 1987. p. 318.

19. Freidson E. Profession of medicine. A study of sociology of applied knowledge. New York, Hagerstown, San Francisco, London: Harper and Row Publ; 1970. p. 278-97.

20. Freidson E. Patients' views of medical practice. A study of subscribers to a prepaid medical plan in the Bronx. Chicago and London: The University of Chicago Press; 1980. p. 146-7.

21. Kreps GL, Neuhauser L. Editors' introduction. Ehealth and the delivery of health care. J Comput-Mediat Comm. 2010;3:364.

22. Eysenbach G. What is e-health? J Med Internet Res [Internet]. 2001 [cited 2016 Jan 20];3(2):e20. Available from: www.jmir.org/2001/2/e20.

23. Hardey M. Doctor in the house: the Internet as a source of lay health knowledge and the challenge to expertise. Sociol Health Ill. 1999;21(6):820-35.

24. Goldstein DE. Communities of suffering and the Internet. In: RM. Packard, PJ. Brown, RL. Berkelman, H. Frumkin (eds). Emerging illnesses and society. Negotiating the public health agenda. Baltimore, London The John Hopkins University Press; 2004. p. 121-38.

25. Seale C. New directions for critical internet health studies: representing cancer experience on the web. Sociol Health Ill. 2005;27(4):515-40.
26. Kivits J. Everyday health and the Internet: a mediated health perspective on health information seeking. Sociol Health Ill. 2009;31(5):673.

27. Griffiths F, Cave J, Boardman F, et al. Social networks - the future for health care delivery. Soc Sci Med. 2012;75(12):2234.

28. Skrzypek M. Dominacja i autorytet medycyny w realiach współczesnej opieki zdrowotnej. W nurcie dyskusji nad Roberta Strausa koncepcją socjologii medycyny. In: S. Fel, M. Wódka (ed). Godność osoby ludzkiej w społeczeństwie i gospodarce. Księga pamiątkowa ku czci śp. Księdza Profesora Franciszka J. Mazurka. Lublin: Wydawnictwo KUL; 2014 p. 341-55.

29. Maksymowicz A. Internet a medycyna. Przemiany relacji zachodzących pomiędzy pacjentami a lekarzami na przykładzie portali oceniających lekarzy. Studia Humanistyczne AGH. 2014;13(1):103.

30. Sillence E, Briggs P, Harris PR, et al. How patients evaluate and make use of onlline health information? Soc Sci Med. 2007;64:1853-62.

31. Freidson E. The changing nature of professional control. Annu Rev Sociol. 1984;10:4-5.

32. Oakes JM, Rossi PH. The measurement of SES in health research: current practice and steps toward a new approach. Soc Sci Med. 2003;56(4):76984.

33. euro.who.int [Internet]. Social inequalities in health in Poland (2012); c2012 [cited 2018 Apr 27]. Available from: http://www.euro.who.int/ en/countries/poland/publications/social-inequalities-in-health-in-poland-2012.

34. ec.europa.eu [Internet]. European Community Household Panel; c2001 [cited 2018 Apr 27]. Available from: http://ec.europa.eu/eurostat/web/microdata/european-community-household-panel.

35. Hernandez-Quevedo C, Jones AM, Lopez-Nicolas A, et al. Socioeconomic inequalities in health: a comparative longitudinal analysis using the European Community Household Panel. Soc Sci Med. 2006;63:1246-61.

36. Zatonski W, McMichael AJ, Powles JW. Ecological study of reasons for sharp decline in mortality from ischaemic heart disease in Poland since 1991. BMJ. 1998;316:1047-51.

37. Zatonski W. The east-west health gap in Europe - what are the causes? Eur J Public Health. 2007;17(2):121.

38. Szasz TS, Hollender MH. A contribution to the philosophy of medicine: the basic models of the doctor-patient relationship. In: Stoeckle JD, ed. Encounters between patients and doctors, an anthology. Cambridge: The MIT Press; 1987. p. 165-77.

39. Skrzypek M, Turska D. Osobowość studentów medycyny deklarujących wybór specjalizacji w zakresie chirurgii w kontekście stylu przyszłej praktyki medycznej. Prz Lek. 2015;72(6):295-301.

40. Freidson E. Professional dominance. The social structure of medical care. Chicago: Aldine Publishing Company; 1977. p. 70-1.

41. Prior L. Belief, knowledge and expertise: the emergence of the lay expert in medical sociology. Sociol Health Ill. 2003;25:41-57.

42. Nettleton S. The sociology of health and illness, 2 ed. Cambridge: Polity Press; 2006. p. 137-8.

Corresponding author

Dr hab. Michał Skrzypek

Dept Clinical Dietetics, Medical University of Lublin

1 Chodźki St., 20-093 Lublin

E-mail: michal.skrzypek@umlub.pl 